\title{
Karakteristik Individu, Motivasi dan Kinerja Pelaksana Operasional BUM Desa
}

\author{
Sucahyo Heriningsih ${ }^{1}$,Lita Yulita Fitriyani ${ }^{2}$, Dwi Sudaryati ${ }^{3}$ \\ Faculty of Economic and Bussiness, UPN "Veteran" Yogyakarta 1,2,3 \\ $\underline{\text { heriningsih_s@yahoo.com }}^{1}$ lita.yulita@upnyk.ac.id $^{2} \underline{\text { dwi.sudaryati@upnyk.ac.id }}^{3}$
}

\begin{abstract}
This study aims to determine the effect of individual characteristics and motivation on the performance of BUMDesa operational operators in Bantul Regency. This study uses a survey method that is data collected using a questionnaire. Populations in this study were operational operators of BUMDesa in Bantul Regency as many as 82 people, and the selected sample of 54 people. The sampling method uses convinience sampling method. The collected data is then analyzed using the multiple linear regression analysis method. The results showed that the work experience and motivation affect the performance of BUMDesa, while gender, education and age did not affect the performance of BUMDesa. This shows that education and age do not guarantee a person's ability to carry out their duties and obligations. The results of this study are expected to be considered by the Village Government in preparing Human Resources to manage the BUMDesa. If BUMDesa is managed by the right Human Resources, has qualified capabilities and appropriate qualifications, then BUMDes can run according to the plans that have been made.
\end{abstract}

Keywords: BUMDes, Human Resources, Performance, Individual Characteristics, Motivation

\begin{abstract}
ABSTRAK
Penelitian ini bertujuan untuk mengetahui pengaruh karakteristik individu dan motivasi terhadap kinerja pelaksana operasional BUMDesa yang ada di Kabupaten Bantul. Penelitian ini menggunakan metode survey yaitu data dikumpulkan dengan menggunakan kuesioner. Populasi dalam penelitian ini adalah pelaksana operasional BUMDesa di Kabupaten Bantul sebanyak 82 orang, dan sampel terpilih sebanyak 54 orang. Metode Pengambilan sampel menggunakan metode convinience sampling. Data yang terkumpul kemudian dianalisis dengan metode analisis regresi linier berganda. Hasil penelitian menunjukkan bahwa pengalaman dan motivasi berpengaruh terhadap kinerja BUMDesa, sedangkan jenis kelamin, pendidikan dan usia tidak berpengaruh terhadap kinerja BUMDesa. Hal ini menunjukkan bahwa pendidikan dan usia tidak menjamin kemampuan seseorang dalam melakukan tugas dan kewajibannya. Hasil penelitian ini diharapkan dapat dijadikan pertimbangan bagi Pemerintah Desa dalam menyiapkan Sumber Daya Manusia untuk mengelola BUM Desa. Jika BUMDesa dikelola oleh Sumber Daya Manusia yang tepat, memiliki
\end{abstract}


kemampuan yang mumpuni serta kualifikasi yang sesuai, maka BUMDesa dapat berjalan sesuai dengan rencana yang telah dibuat.

Kata Kunci: BUMDesa, Sumber Daya Manusia, Kinerja, Karakteristik Individu, Motivasi

\section{PENDAHULUAN}

Badan Usaha Milik Desa (BUMDes) merupakan suatu lembaga ekonomi dengan modal usahanya dibangun atas inisiatif masyarakat desa dan menganut asas mandiri. Ini berarti pemenuhan modal usaha BUMDes harus bersumber dari masyarakat sendiri.Meskipun demikian, tidak menutup kemungkinan BUMDes dapat mengajukan pinjaman modal kepada pihak luar, seperti dari pemerintah desa atau pihak lainnya. Menurut Undang-Undang Nomor 6 Tahun 2014 Tentang Desa dinyatakan bahwa BUMDes adalah badan usaha yang seluruh atau sebagian besar modalnya dimilikioleh desa melalui penyertaan secara langsung yang berasal dari kekayaan desa yang dipisahkan guna mengelola aset, jasa pelayanan, dan usaha lainnya untuk sebesar-besarnya kesejahteraan masyarakat Desa.

Kinerja merupakan gambaran mengenai tingkat pencapaian suatu pelaksanaan suatu program kegiatan atau kebijakan dalam mewujudkan sasaran, tujuan, visi dan misi organisasi yang di tuangkang melalui perencanaan suatu strategi organisasi. Keberhasilan suatu organisasi salah satunya ditentukan oleh kinerja sumber daya manusia yang dimilikinya. Dalam konteks entitas BUM Desa, pelaksana operasional BUMDesa menjadi salah satu ujung tombak pelaksanaan tata kelola BUMDesa. Keberhasilan pelaksana operasional dalam mengerjakan perannya sesuai dengan kualitas dan kuantitas sesuai dengan persyaratan yang ada inilah yang selanjutnya disebut dengan kinerja. Dalam hal ini, kinerja BUMDesa ditentukan oleh pelaksana operasional dalam menjalankan tugasnya sesuai dengan peraturan perundang-undangan yang berlaku.

Sebagian besar bisnis yang ditangani oleh BUMDes tidak berkembang dengan baik, artinya jenis bisnis yang ditangani oleh BUMDes masih sama sejak dibentuk hingga sekarang. Sebagian besar potensi desa belum dikembangkan. Hasil penelitian menunjukkan sebagian besar manajer BUMDes tidak memiliki pengalaman kerja dan latar belakang pendidikan yang relevan dengan pekerjaan mereka. Oleh karena itu, pelatihan pendidikan dan kewirausahaan diperlukan bagi manajer BUMDes, sehingga mereka dapat mengembangkan bisnis untuk meningkatkan pendapatan dan pendapatan BUMDes (Hidayati, 2015).

Karakteristik BUMDes sebagai institusi dalam sumber daya manusia adalah dalam bentuk badan hukum yang merupakan pusat kegiatan ekonomi penduduk desa, salah satu sumber pendapatan pedesaan, dan melayani penduduk desa. Kita dapat melihat bahwa karakteristik BUMDes adalah sumber pendapatan pedesaan. Di sini, para manajer dituntut untuk dapat mengelola BUMDes untuk berkontribusi pada pendapatan pedesaan (Sayuti, 2011).

Berdasarkan latarbelakang diatas serta untuk memperbaiki dan meningkatkan kinerja pelaksana operasional BUMdesa, maka rumusan masalah dalam penelitian ini adalah: 1). Apakah karakteristik individu memiliki pengaruh terhadap kinerja pelaksana pengelola BUMdesa, 2). Apakah motivasi memiliki pengaruh terhadap kinerja pelaksana pengelola BUMdesa. 


\section{TINJAUAN PUSTAKA DAN PENGEMBANGAN HIPOTESIS BUMDesa}

Menurut Permendesa PDTT Nomor 4 Tahun 2015 bahwa Badan Usaha Milik Desa, selanjutnya disebut BUM Desa, adalah badan usaha yang seluruh atau sebagian besar modalnya dimiliki oleh Desa melalui penyertaan secara langsung yang berasal dari kekayaan Desa yang dipisahkan guna mengelola aset, jasa pelayanan, dan usaha lainnya untuk sebesar-besarnya kesejahteraan masyarakat Desa.BUMDes merupakan badan usaha yang ditetapkan melalui Peraturan Desa berdasarkan hasil keputusan Musyawarah Desa. Pasal 7 Permendesa PDTT Nomor 4 Tahun 2015BUM Desa dapat terdiri dari unit-unit usaha yang berbadan hukum. Keberadaan unit usaha yang berbadan hukum tersebut dapat berupa lembaga bisnis yang kepemilikan sahamnya berasal dari BUM Desa dan masyarakat.

Pengelolaan BUM Desa diatur pada Pasal 9 Permendesa PDTT Nomor 4 Tahun 2015, yaitu organisasi pengelola BUM Desa terpisah dari organisasi Pemerintahan Desa.Susunan kepengurusan organisasi pengelola BUM Desa terdiri atas penasihat; pelaksana operasional; dan pengawas. Masing-masing pengurus mempunyai tugas dan peranan yang berbeda. Kepengurusan BUM Desa dipilih oleh masyarakat Desa melalui Musyawarah Desa sesuai dengan ketentuan dalam Peraturan Menteri tentang Pedoman Tata Tertib dan Mekanisme Pengambilan Keputusan Musyawarah Desa.

Tugas mengurus dan mengelola BUM Desa dilaksanakan oleh pelaksana operasional dengan tujuan untuk menjamin agar BUMDesa dapat berkembang dengan baik. Pelaksana Operasional BUM Desa adalah perorangan yang direkrut dan dipilih secara terbuka dalam musyawarah desa. Pelaksana operasional terdiri dari ketua (direktur), sekretaris, bendahara dan para manajer unit/kepala unit atau nama lain sesuai kebutuhan serta kearifan lokal masing-masing. Menurut pasal 13 dinyatakan pula bahwa Pelaksana Operasional dapat dibantu karyawan sesuai dengan kebutuhan dan harus disertai dengan uraian tugas berkenaan dengan tanggung jawab, pembagian peran dan aspek pembagian kerja lainnya.

Terdapat beberapa persyaratan pelaksana operasional sesuai pasal 14 Permendesa PDTT Nomor 4 Tahun 2015, antara lain:
a. masyarakat Desa yang mempunyai jiwa wirausaha;
b. berdomisili dan menetap di Desa sekurang-kurangnya 2 (dua) tahun;
c. berkepribadian baik, jujur, adil, cakap, dan perhatian terhadap usaha ekonomi Desa; dan
d. pendidikan minimal setingkat SMU/Madrasah Aliyah/SMK atau sederajat;

\section{Kinerja}

Kinerja adalah hasil-hasil fungsi kegiatan seseorang atau kelompok dalam suatu organisasi yang dipengaruhi oleh berbagai faktor untuk mencapai tujuan organisasi dalam periode tertentu. Fungsi kegiatan yang dimaksud yaitu pelaksanaan hasil kegiatan seseorang atau kelompok yang menjadi wewenang dan tanggung jawabnya dalam suatu organisasi. Pelaksanaan hasil prestasi kerja tersebut diarahkan untuk mencapai tujuan organisasi dalam jangka waktu tertentu. Pengertian kinerja (performance work) adalah kualitas dan kuantitas kerja yang dicapai oleh seorang karyawan dalam menjalankan fungsinya sesuai dengan 
tanggung jawab yang diberikan kepadanya(Razak, Sarpan and Ramlan, 2018). Kinerja karyawan diharapkan dapat meningkatkan kinerja organisasi secara keseluruhan. Memperoleh kinerja tingkat tinggi karyawan diperlukan untuk mencapai kinerja organisasi yang optimal(Rachmayanthy, 2016).

Menurut Mahsun (2006), kinerja (performance) sebagai suatu gambaran mengenai tingkat pelaksanaan suatu kegiatan atau program atau kebijakan dalam mewujudkan sasaran, tujuan misi dan visi organisasi yang tertuang dalam strategic planning suatu organisasi. Dengan demikian, kinerja dipengaruhi oleh faktor pendukung dan penghambat berjalannya suatu pencapaian kinerja yang dapat berasal dari intern maupun ekstern.

\section{Karakteristik Individu}

Wanita pada umumnya disosialisasikan ke dalam peran gender yang ditentukan secara sosial, seperti merawat orang lain dan mementingkan hubungan, sedangkan pria disosialisasikan agar memiliki penegasan diri dan kompetensi (Kim and Jeong, 2018). Hasil penelitian (Igbaria and Shayo, 1997) menunjukkan bahwa pria mengalami kemajuan karier yang lebih baik daripada wanita. Meskipun wanita memiliki peringkat kinerja pekerjaan yang mirip dengan pria, karyawan pria yang paling mungkin mencapai kinerja tinggi karena kemampuan dan upaya mereka. Namun hasil penelitian (Kim and Jeong, 2018) menunjukan bahwa perempuan lebih etis dan menolak risiko daripada laki-laki, sehingga banyak peneliti di bidang akuntansi dan keuangan melihat efek dari eksekutif perempuan pada informasi akuntansi dan kinerja keuangan dengan meningkatnya eksekutif perempuan di perusahaan.Karyawan pria cenderung mandiri, suka bertualang, dan ambisius, dan lebih siap untuk menghadapi tekanan tinggi dan jam kerja yang panjang. Karyawan wanita berorientasi pada detail dan bijaksana, pendengar yang baik, dan mampu mengakomodasi kebutuhan pelanggan(Lee and Cheng, 2018). Hasil penelitian (Indartono dan Chen, 2010), mengungkapkan meskipun karyawan wanita ditemukan mencapai kinerja yang lebih tinggi daripada karyawan pria, hasil penelitian ini mengungkapkan bahwa karyawan pria memiliki efek karakteristik tugas yang lebih tinggi terhadap kinerja. Karena itu, karyawan pria lebih percaya diri daripada karyawan wanita.

Pengalaman yang lebih lama, memungkinkan individu untuk mempertahankan tingkat kinerja yang lebih tinggi dengan sedikit usaha. Artinya, hubungan antara upaya dan kinerja lemah dengan praktik. Dengan kata lain, kegunaan usaha tergantung pada tingkat perolehan keterampilan dan variabel perbedaan individu yang mempengaruhi tingkat pembelajaran (Hailesilasie, 2009). Pengalaman karyawan dapat didefinisikan sebagai persepsi holistik karyawan tentang hubungan dengan organisasi yang mempekerjakannya yang berasal dari semua pertemuan. di sepanjang perjalanan karyawan. Sebuah perusahaan harus benar-benar memahami dan menempatkan dengan karyawannya, baik sebagai individu dan sebagai bagian dari kelompok perwakilan (misalnya generasi), untuk berpikir secara holistik tentang seluruh pengalaman, dan mengakui bahwa persepsi hubungan dimulai sebelum karyawan bergabung dengan perusahaan dan bertahan setelah mereka pergi (Plaskoff, 2017). Penekanan pada pengalaman kerja sebelumnya sebagai prediktor kinerja berpusat pada keyakinan bahwa melalui pengalaman seperti itu individu memperoleh peluang lebih besar untuk menumbuhkan pengetahuan, keterampilan, dan 
kemampuan baru, dan untuk memperbaiki yang sudah ada (Schmidt et al., 1986). Individu dianggap dapat memanfaatkan koleksi pengalaman ini dan pada gilirannya menikmati tingkat kinerja yang lebih tinggi ketika mereka bekerja di pekerjaan atau tugas yang sama seperti yang mereka lakukan di masa lalu.kinerja pekerjaan seseorang meningkat dengan setiap tahun pengalaman karir terkait sebelumnya selama mereka menempatkan nilai tinggi pada pengalaman itu. Sebaliknya, kinerja seseorang menurun dengan setiap tahun pengalaman karir terkait sebelumnya ketika pengalaman itu dianggap memiliki sedikit atau tidak ada nilai pada posisi saat ini (Mahony, Klimchak and Morrell, 2012).

Faktor lain yang mendukung tingkat kinerja karyawan adalah pendidikan (Ni Komang Ayu Sri Swandari, Setiawina and Marhaeni, 2017). Menurut (Roni, Moein and Effendi, 2018) bahwa kompetensi berpengaruh terhadap kinerja karyawan. Kompetensi dapat diperoleh dari pendidikan maupun pelatihan. Bahkan dalam pasal 14 Permendesa PDTT Nomor 4 Tahun 2015 tentang persyaratan pelaksana operasional adalah pendidikan.Hasil penelitian (Hashim and Wok, 2014) menunjukkan bahwa karyawan yang tidak berpendidikan tinggi maka organisasiakan lebih melindunginya. Ini dapat mengurangi tingkat kepercayaan mereka untuk memproyeksikan kompetensi mereka yang sebenarnya. Sebaliknya, untuk karyawan yang lebih tua, karena latar belakang pendidikan mereka dan mereka dikenal karena keahlian mereka, mereka bangga untuk membuktikan prestasi mereka.Peluang kerja telah menurun untuk karyawan muda, terutama bagi mereka yang memiliki pendidikan rendah atau menengahKaryawan berpendidikan menengah sangat mirip dengan karyawan berpendidikan rendah sehubungan dengan tuntutan pekerjaan, sumber daya pekerjaan, kesejahteraan, kesehatan, dan kinerja. Dibandingkan dengan karyawan berpendidikan tinggi, mereka mengalami tuntutan pekerjaan yang lebih sedikit, lebih sedikit sumber daya pekerjaan (Akkermans et al., 2009). Latar belakang pendidikan yang lebih tinggi berarti basis pengetahuan yang kuat dan pelatihan profesional yang mendalam, yang berkontribusi pada kapasitas untuk secara cepat memperoleh dan mengakumulasi keterampilan profesional, dan karenanya, kemampuan yang lebih baik untuk menganalisis dan memahami bisnis perusahaan. Semua faktor ini menguntungkan efisiensi dan hasil kerja. Menawarkan berbagai layanan sesuai dengan atribut sumber daya manusia dapat meningkatkan kinerja perusahaan secara keseluruhan (Lee and Cheng, 2018).

Kinerja meningkat seiring bertambahnya usia hingga titik tertentu dan di luar titik itu kinerja menurun seiring bertambahnya usia. Hasil penelitian (Hailesilasie, 2009) menunjukkan bahwa karyawan yang berusia lanjut memiliki kemungkinan 88 persen lebih tinggi untuk kinerja yang sangat baik daripada karyawan yang lebih muda.Dengan bertambahnya usia, karyawan cenderung merasa bahwa mereka perlu mendapatkan manfaat secara proporsional untuk pengalaman mereka daripada berdasarkan prestasi. Menurut (Kamery, 2004) bahwa karyawan yang lebih tua harus mengetahui pekerjaan dengan lebih baik karena kurva belajar dan pengalaman kerja mereka, dan ini juga dikonfirmasi oleh latihan lapangan. Hasil penelitian (Hashim and Wok, 2014) menunjukkan bahwa berdasarkan penilaian yang dilakukan oleh karyawan yang lebih tua itu sendiri dan atasan mereka, ditemukan bahwa mereka kompeten, berkinerja baik, dan dapat dilatih. Pengetahuan dan pengalaman karyawan yang lebih tua menjadi 
sumber daya yang berguna untuk membimbing karyawan muda. Meskipun karyawan yang lebih tua mungkin tidak bekerja untuk waktu yang lama, itu tetap layak untuk melatih mereka, karena pelatihan berkontribusi secara signifikan terhadap kompetensi dan kinerja mereka. Ini dapat meningkatkan skenario saat ini di mana beberapa karyawan yang lebih tua kemungkinan besar tidak akan mendapatkan pelatihan. Ini akan memotivasi karyawan yang lebih tua untuk melanjutkan layanan mereka. Mereka juga akan merasa dihargai dan rela berbagi pengetahuan dan pengalaman berharga mereka dengan rekan-rekan mereka yang lebih muda. Karyawan muda menghadapi banyak tantangan dan tugas baru: mereka tidak punya waktu luang, lebih banyak tanggung jawab, harus mengatur waktu mereka dengan cara baru, dan harus lebih fleksibel. Semua tugas dan tanggung jawab baru ini, serta proses sosialisasi dalam pekerjaan mereka, berpotensi menyebabkan ketidakamanan dan tekanan(Akkermans et al., 2009).

$H_{1}$ : Karakteristik Individu (Pengalaman, Pendidikan, Jenis Kelamin, Usia) berpengaruh terhadap Kinerja Pengelola Operasional BUM Desa

\section{Motivasi}

Motivasi adalah elemen penting dalam diri seseorang, dan berfungsi untuk mewujudkan keberhasilan upaya atau tugas yang diemban oleh seseorang. Motivasi dari atasan adalah pengetahuan dan perhatian pada perilaku bawahan sebagai faktor langsung dalam keberhasilan organisasi(Rachmayanthy, 2016).Teori yang terkait dengan motivasi karyawan adalah teori ekuitas. Teori ini menunjukkan bahwa individu membandingkan kinerja dan kompensasi mereka dengan kinerja dan kompensasi rekan kerja mereka dan bertindak untuk memperbaiki ketidaksetaraan (Kamery, 2004).

Ketika seorang karyawan memiliki kemampuan yang wajar untuk melakukan pekerjaan dan cukup tahu peran yang diharapkan maka peningkatan motivasi akan membawa peningkatan kinerja individu(Hailesilasie, 2009). Hasil penelitian (Rachmayanthy, 2016) menunjukkan bahwa motivasi memiliki hubungan positif yang kuat dengan kinerja karyawan.

$\mathrm{H}_{2}$ : Motivasi berpengaruh terhadap Kinerja Pelaksana Operasional BUM Desa

\section{METODE PENELITIAN}

\section{Rancangan Penelitian, Populasi dan Sampel}

Rancangan penelitian ini adalah cross-sectional dan korelasional. Populasi dalam penelitian ini adalah semua pelaksana operasional BUMDesa di Kabupaten Bantul sebanyak 82 orang. Pelaksana operasional bertugas mengurus dan mengelola BUM Desa dengan tujuan untuk menjamin agar BUM Desa dapat berkembang dengan baik. Pelaksana operasional terdiri dari ketua (direktur), sekretaris, bendahara dan para manajer unit/kepala unit atau nama lain sesuai kebutuhan serta kearifan lokal masing-masing.Metode pengambilan sampel dalam penelitian ini menggunakan metode convenience sampling dan sampel terpilih sebanyak 54 orang. Convenience sampling adalah pengambilan sampel didasarkan pada ketersediaan elemen dan kemudahan untuk mendapatkannya. Sampel terpilih karena sampel tersebut ada pada tempat dan waktu yang tepat. Teknik sampling ini merupakan metode yang termurah dan hemat waktu. 


\section{Pengukuran Variabel}

Penelitian ini menggunakan data primer berupa kuesioner karena kesesuaian dalam hal pengumpulan data dari sekelompok besar responden dengan biaya rendah, dalam waktu singkat dan menggunakan lebih sedikit energi (Sekaran, 2003). Kuesioner dapat berupa format jawaban terbuka atau jawaban tertutup. Dalam penelitian ini digunakan format jawaban-tertutup yang lebih mudah untuk dianalisis. Kuesioner dirancang sesuai dengan hipotesis penelitian dan variabel yang digunakan dalam penelitian ini. Skala Likert lima poin digunakan karena skala Likert yang merata memungkinkan peneliti untuk menggali informasi yang tepat dari responden mengenai situasi yang telah mereka alami. Kuesioner dikembangkan setelah meninjau literatur yang ada tentang karakteristik individu, motivasi dan kinerja pelaksana operasional BUMDesa. Variabel dependen untuk penelitian ini adalah kinerja pelaksana operasional BUMDesa, sedangkan variabel independen adalah karakteristik individu, motivasi.

\section{Uji kualitas data meliputi uji reliabilitas dan uji validitas.}

Penelitian ini menggunakan nilai korelasi antara masing-masing butir pertanyaan terhadap total score masing-masing butir pertanyaan per variabelnya, dengan melihat score correlation pearson dan nilai signifikansi untuk uji validitas, dan uji reliabilitas dengan menggunakan uji statistic Cronbach Alpha. Validitas menentukan apakah instrumen penelitian benar-benar mengukur bahwa itu dimaksudkan untuk mengukur atau seberapa jujur hasil penelitian. Reliabilitas adalah kemampuan ukuran untuk menghasilkan hasil yang konsisten ketika entitas yang sama diukur dalam kondisi yang berbeda, dan sekali koefisien alpha Cronbach di atas 0,70, instrumen dianggap dapat diandalkan. Untuk penelitian ini, koefisien alpha Cronbach dari semua variabel penelitian berada di atas 0,70. Dan untuk reliabilitas semua butir-butir pertanyaan masing-masing variabel menunjukkan bahwa nilai Alpha terletak di antara 0,8 sampai dengan 1,0 sehingga dapat disimpulkan bahwa semua butir pertanyaan dalam kuesioner adalah reliable.

\section{HASIL PENGUJIAN HIPOTESIS}

\section{Statistik Deskriptif}

Hasil analisis statistik deskriptif pada Tabel 1 menunjukkan bahwa karyawan dengan jenis kelamin pria sebanyak 36 orang atau $66,7 \%$ dan wanita sebanyak 18 orang atau 33,3\%. Hal ini berarti bahwa karyawan BUMDes mayoritas adalah berjenis kelamin pria.

Hasil analisis statistik deskriptif pada Tabel 2 bahwa lama bekerja karyawan menunjukkan nilai minimal 0,30, maximal 3,50 dan mean 1,66. Hal ini berarti bahwa lama bekerja karyawan paling sedikit 3,6 bulan dan paling lama 3 tahun 6 bulan. Rata-rata masa kerja karyawan adalah 1 tahun 8 bulan.

Hasil analisis statistik deskriptif pada Tabel 3 menunjukkan bahwa karyawan dengan pendidikan SMA sebanyak 24 orang $(44,4 \%)$, D3 sebanyak 4 orang $(7,4 \%)$, S1 sebanyak 25 orang $(46,3 \%)$ dan S2 sebanyak 1 orang $(1,9 \%)$. Hal ini berarti bahwa karyawan BUMDes sudah memiliki tingkat pendidikan yang baik sebab hamper lebih dari sebagian berpendidikan minimal diploma. 
Hasil analisis statistik deskriptif pada Tabel 4 menunjukkan bahwa 8 orang berusia $<30$ tahun, 11 orang berusia antara 30-39 tahun, 21 orang berusia antara 40-49 tahun dan 14 orang berusia $>50$ tahun. Hal ini berarti bahwa mayoritas karyawan BUMDes berusia 40-49 tahun sebanyak 38,9\% dan merupakan usia produktif.

\section{Hasil Uji F}

\begin{tabular}{|c|c|c|c|c|c|c|}
\hline \multicolumn{7}{|c|}{ Tabel s. Hasil U Ji F } \\
\hline Mode & & $\begin{array}{l}\text { Sum of } \\
\text { Squares }\end{array}$ & df & Mean Square & $\mathrm{F}$ & Sig. \\
\hline \multirow[t]{3}{*}{1} & Regression & 1.995 & 5 & .399 & 3.560 & $.008^{b}$ \\
\hline & Residual & 5.380 & 48 & .112 & & \\
\hline & Total & 7.375 & 53 & & & \\
\hline
\end{tabular}

Hasil uji F pada tabel 5 menunjukkan nilai F sebesar 3,560 dan Sig. sebesar 0,008 $<0,05$, yang berarti bahwa model penelitian ini layak untuk digunakan dan dilakukan pengujian lebih lanjut.

\section{Hasil Uji t}

Tabel 6. Hasil Uji t

\begin{tabular}{|c|c|c|c|c|c|c|}
\hline \multirow{2}{*}{\multicolumn{2}{|c|}{ Model }} & \multicolumn{2}{|c|}{$\begin{array}{c}\text { Unstandardized } \\
\text { Coefficients }\end{array}$} & \multirow{2}{*}{$\begin{array}{c}\text { Standardized } \\
\text { Coefficients }\end{array}$} & \multirow[b]{2}{*}{$\mathrm{t}$} & \multirow[b]{2}{*}{ Sig. } \\
\hline & & $\mathrm{B}$ & Std. Error & & & \\
\hline 1 & (Constant) & 1.645 & .468 & & 3.513 & .001 \\
\hline & $\begin{array}{l}\text { Jenis } \\
\text { Kelamin }\end{array}$ & .156 & .099 & .199 & 1.577 & .121 \\
\hline & Pengalaman & .135 & .055 & .312 & 2.464 & .017 \\
\hline & Pendidikan & -.008 & .048 & -.022 & -.173 & .863 \\
\hline & Usia & .064 & .047 & .173 & 1.358 & .181 \\
\hline & Motivasi & .328 & .121 & .353 & 2.714 & .009 \\
\hline
\end{tabular}

\section{Pengaruh Karakteristik Individu terhadap Kinerja}

Hasil uji t menunjukan bahwa nilai Sig. variable lama bekerja sebesar 0,017 yang berarti bahwa nilai Sig tersebut lebih kecil dari 0,05(5\%). Dengan demikian variable pengalaman berpengaruh signifikan terhadap kinerja karyawan BUMDes.Hasil penelitian ini sejalan dengan penelitian (Ni Komang Ayu Sri Swandari, Setiawina and Marhaeni, 2017) bahwa pengalaman berpengaruh terhadap kinerja karyawan BUMDes. Pengalaman seseorang akan dapat meningkatkan ketrampilan seseorang yang akhirnya dapat meningkatkan kinerjanya. Sedangkan nilai Sig. variable jenis kelamin, pendidikan dan usia menunjukkan nilai lebih besar dari 0,05(5\%) yang berarti bahwa variable-variabel tersebut tidak berpengaruh terhadap kinerja karyawan BUMDes.

Hasil penelitian ini mendukung penelitian(Hailesilasie, 2009)yang menunjukkan bahwa ketika tingkat pendidikan meningkat, kinerja individu cenderung menurun. Para karyawan dengan latar belakang pendidikan yang lebih tinggi menunjukkan kemungkinan 50 persen lebih rendah untuk kinerja yang lebih 
tinggi dibandingkan dengan mereka yang memiliki kualifikasi pendidikan yang lebih rendah.

Usia sama sekali bukan satu-satunya faktor dominan yang menentukan efisiensi dan ketahanan (Kroll, 2003).Kinerja pekerja yang lebih tua dikontribusikan oleh kompetensi dan kemampuan pelatihan mereka. Namun, kompetensi adalah prediktor yang lebih baik daripada kemampuan melatih terlepas dari kategori pekerja yang lebih tua(Hashim and Wok, 2014).

\section{Pengaruh Motivasi terhadap Kinerja}

Hasil uji t menunjukan bahwa nilai Sig. variable motivasi sebesar 0,009 lebih kecil dari 0,05 (5\%), sehingga motivasi berpengaruh signifikan terhadap kinerja karyawan BUMDes. Hal ini berarti bahwa peningkatan motivasi individu untuk bekerja meningkatkan kinerja karyawan, sesuai dengan (Rachmayanthy, 2016). Karyawan akan memiliki tingkat motivasi yang lebih tinggi ketika mereka merasa bahwa manajemen peduli dengan kesejahteraan mereka, ketika mereka terlibat dalam proses manajemen, dan ketika lingkungan manajemen-tenaga kerja positif. Jika pekerja merasa diperlakukan dengan adil dan hormat, sikap ini akan mengembangkan dan membimbing perilaku mereka ke arah yang positif(Kamery, 2004).Hasil penelitian ini juga mendukung penelitian (Hailesilasie, 2009) yang menyatakan bahwa motivasi mempengaruhi kinerja dengan mempengaruhi cara individu mengalokasikan upaya untuk tugas-tugas dan kadang-kadang karyawan mungkin tidak diminta untuk mengerahkan banyak upaya untuk melakukan.

\section{Koefisien Determinasi}

Tabel 7. Koefisien Determinasi

\begin{tabular}{ccccc}
\hline Model & $\mathrm{R}$ & $\mathrm{R}$ Square & Adjusted R Square & $\begin{array}{c}\text { Std. Error of the } \\
\text { Estimate }\end{array}$ \\
\hline 1 & $.520^{\mathrm{a}}$ & .271 & .195 & .33478 \\
\hline
\end{tabular}

Hasil koefisien determinasi menunjukkan nilai Adjusted R Square sebesar 0,195 atau 19,5\% yang berarti bahwa variable karakteristik individu (jenis kelamin, pengalaman, pendidikan, usia) dan motivasi mampu mempengaruhi variable kinerja karyawan BUMDes sebesar 19,5\% sedangkan 80,5\% dipengaruhi oleh variable lain yang tidak diteiliti dalam penelitian ini. Dengan hasil ini memberikan peluang bagi penelitian selanjutnya untuk menggali faktor-faktor lain yang mempengaruhi kinerja karyawan BUMDes, selain faktor internal yang ada dalam diri karyawan.

\section{KESIMPULAN DAN SARAN}

Badan Usaha Milik Desa adalah satu-satunya lembaga ekonomi yang dimiliki oleh desa, yang diharapkan dapat meningkatkan perekonomian desa, sehingga perlu dikelola oleh manajer profesional untuk mencapai tujuan BUMDes. Hasil penelitian menunjukkan bahwa pengalaman dan motivasi berpengaruh terhadap kinerja pelaksana operasional BUMDesa, namun jenis kelamin, pendidikan dan usia tidak berpengaruh terhadap kinerja pelaksana operasional BUMDesa. Hal ini memberikan masukan bagi BUMDesa agar dapat mempertimbangkan faktor-faktor tersebut dalam pengelolaan sumber daya 
manusianya. Dengan demikian, manfaat adanya BUMDesa benar-benar dapat dirasakan oleh masyarakat.

\section{REFERENCES}

Akkermans, J. et al. (2009) 'Fresh and healthy?: Well-being, health and performance of young employees with intermediate education', Career Development International, 14(7), pp. 671-699. doi: 10.1108/13620430911005717.

Chen, C. V. (no date) 'Moderation of Gender on the Relationship Between Task', Structural Equation Modeling, 2, pp. 195-223.

Hailesilasie, G. (2009) 'Determinants of public employees' performance: Evidence from Ethiopian public organizations', International Journal of Productivity and Performance Management, 58(3), pp. 238-253. doi: 10.1108/17410400910938841.

Hashim, J. and Wok, S. (2014) 'Competence, performance and trainability of older workers of higher educational institutions in Malaysia', Employee Relations, 36(1), pp. 82-106. doi: 10.1108/ER-04-2012-0031.

Hidayati, U. M. I. (2015) 'Performance Analysis of Village-Owned Enterprise Managers as a Basic of Designing Education and Training', European Journal of Business and Management, 7(32), pp. 143-147. Available at: http://citeseerx.ist.psu.edu/viewdoc/download?doi=10.1.1.735.4376\&rep= rep1\&type=pdf.

Igbaria, M. and Shayo, C. (1997) 'The Impact of Race and Gender Differences on Job performance Evaluations and Career Success', Equal Opportunities International, 16(8), pp. 12-23. doi: 10.1108/eb010703.

Kamery, R. H. (2004) 'Employee motivation as it relates to effectiveness, productivity, and performance', Proceedings of the Academy of Legal, Ethical and Regulatory Issues, 8(2), pp. 139-144.

Kim, H. A. and Jeong, S. W. (2018) 'Gender diversity in employees and discretionary accruals: the Korean evidence', International Journal of Accounting and Information Management, 26(3), pp. 362-383. doi: 10.1108/IJAIM-07-2016-0068.

Lee, C. C. and Cheng, P. Y. (2018) 'Effect of the critical human resource attributes on operating performances', Chinese Management Studies, 12(2), pp. 407-432. doi: 10.1108/CMS-10-2017-0296.

Mahony, D. M., Klimchak, M. and Morrell, D. L. (2012) 'The portability of career-long work experience: Propensity to trust as a substitute for valuable work experience', Career Development International, 17(7), pp. 
606-625. doi: 10.1108/13620431211283779.

Ni Komang Ayu Sri Swandari, Setiawina, N. D. and Marhaeni, A. A. I. N. (2017) 'KARYAWAN BUMDes DI KABUPATEN JEMBRANA Fakultas Ekonomi dan Bisnis Universitas Udayana ( UNUD ), Bali , Indonesia PENDAHULUAN Salah satu cara untuk mencapai pertumbuhan ekonomi di wilayah pedesaan adalah melalui pertumbuhan lembaga mikro desa , dan salah s', Jurnal Ekonomi dan Bisnis, 4(VOLUME.06.NO.04.TAHUN 2017), pp. 1365-1394. Available at: https://ojs.unud.ac.id/index.php/ EEB/article/view/24184.

Plaskoff, J. (2017) 'Employee experience: the new human resource management approach', Strategic HR Review, 16(3), pp. 136-141. doi: 10.1108/shr-122016-0108.

Rachmayanthy, R. (2016) 'Influence of organizational structure and job satisfaction on employee performance', Inovasi, 3(1), pp. 1-14.

Razak, A., Sarpan, S. and Ramlan, R. (2018) 'Effect of Leadership Style, Motivation and Work Discipline on Employee Performance in PT. ABC Makassar', Jurnal Aplikasi Manajemen, 15(4), pp. 607-615. doi: 10.21776/ub.jam2017.015.04.07.

Roni, K. A., Moein, A. and Effendi, N. I. (2018) 'Determination of Work Motivation and its Implication on Employee Performance Secretariat of $\mathrm{Kpu}$ Se-Province Jambi', International Review of Management and Marketing, 8(6), pp. 72-77.

Sayuti, H. M. (2011) 'Pelembagaan Badan Usaha Milik Desa (Bumds) Sebagai Penggerak Potensi Ekonomi Desa Dalam Upaya Pengentasan Kemiskinan Dikabupaten Donggal', Jurnal ACADEMICA Fisip Untad, 03(02), pp. $717-728$. 


\section{Appendix}

Tabel 1. Jenis Kelamin

\begin{tabular}{|c|c|c|c|c|c|}
\hline & & Frequency & Percent & Valid Percent & $\begin{array}{c}\text { Cumulative } \\
\text { Percent }\end{array}$ \\
\hline \multirow[t]{3}{*}{ Valid } & Pria & 36 & 66.7 & 66.7 & \multirow{3}{*}{$\begin{array}{r}66.7 \\
100.0\end{array}$} \\
\hline & Wanita & 18 & 33.3 & 33.3 & \\
\hline & Total & 54 & 100.0 & 100.0 & \\
\hline
\end{tabular}

Tabel 2. Lama Bekerja

\begin{tabular}{|c|c|c|c|c|c|}
\hline & & Frequency & Percent & Valid Percent & $\begin{array}{l}\text { Cumulative } \\
\text { Percent }\end{array}$ \\
\hline \multirow{22}{*}{ Valid } & .30 & 1 & 1.9 & 1.9 & 1.9 \\
\hline & .50 & 3 & 5.6 & 5.6 & 7.4 \\
\hline & .60 & 3 & 5.6 & 5.6 & 13.0 \\
\hline & .70 & 3 & 5.6 & 5.6 & 18.5 \\
\hline & .90 & 1 & 1.9 & 1.9 & 20.4 \\
\hline & 1.00 & 5 & 9.3 & 9.3 & 29.6 \\
\hline & 1.10 & 2 & 3.7 & 3.7 & 33.3 \\
\hline & 1.20 & 4 & 7.4 & 7.4 & 40.7 \\
\hline & 1.30 & 1 & 1.9 & 1.9 & 42.6 \\
\hline & 1.40 & 1 & 1.9 & 1.9 & 44.4 \\
\hline & 1.50 & 1 & 1.9 & 1.9 & 46.3 \\
\hline & 1.60 & 1 & 1.9 & 1.9 & 48.1 \\
\hline & 1.70 & 6 & 11.1 & 11.1 & 59.3 \\
\hline & 1.80 & 4 & 7.4 & 7.4 & 66.7 \\
\hline & 2.00 & 4 & 7.4 & 7.4 & 74.1 \\
\hline & 2.10 & 1 & 1.9 & 1.9 & 75.9 \\
\hline & 2.70 & 6 & 11.1 & 11.1 & 87.0 \\
\hline & 2.90 & 1 & 1.9 & 1.9 & 88.9 \\
\hline & 3.00 & 2 & 3.7 & 3.7 & 92.6 \\
\hline & 3.20 & 3 & 5.6 & 5.6 & 98.1 \\
\hline & 3.50 & 1 & 1.9 & 1.9 & 100.0 \\
\hline & Total & 54 & 100.0 & 100.0 & \\
\hline
\end{tabular}

Tabel 3. Pendidikan

\begin{tabular}{|ll|r|r|r|r|}
\hline & & & & Cumulative \\
& & Frequency & Percent & Valid Percent & Percent \\
\hline Valid & SMA & 24 & 44.4 & 44.4 & 44.4 \\
& D3 & 4 & 7.4 & 7.4 & 51.9 \\
& S1 & 25 & 46.3 & 46.3 & 98.1 \\
S2 & 1 & 1.9 & 1.9 & 100.0 \\
& Total & 54 & 100.0 & 100.0 & \\
\hline
\end{tabular}

Tabel 4. Usia

\begin{tabular}{|rl|r|r|r|r|}
\hline & & & & \multicolumn{2}{c|}{$\begin{array}{c}\text { Cumulative } \\
\text { Percent }\end{array}$} \\
\hline Valid & Frequency & Percent & Valid Percent & 14.8 \\
& $30-39$ & 8 & 14.8 & 14.8 & 35.2 \\
& 11 & 20.4 & 20.4 & 74.1 \\
& $40-49$ & 21 & 38.9 & 38.9 & 100.0 \\
& $>50$ & 14 & 25.9 & 25.9 & \\
& Total & 54 & 100.0 & 100.0 & \\
\hline
\end{tabular}

